九州大学学術情報リポジトリ

Kyushu University Institutional Repository

\title{
Detection of Tricholoma Matsutake in Soil After FOREST Fire in a Pinus Densiflora Forest in Korea
}

Cha, Joo Young

Field Science Center for Northern Biosphere, Hokkaido University

Chun, Kun Woo

Division of Forest Resource, College of Forest and Environmental Sciences, Kangwon National University

Lee, Sang Yong

Division of Forest Resource, College of Forest and Environmental Sciences, Kangwon National University

Lee, Si Young

The Professional Graduate School of Disaster Prevention Technology, Kangwon National University

他

https://doi.org/10.5109/16101

出版情報：九州大学大学院農学研究院紀要. 54 (2)，pp.261-265，2009-10-29. Faculty of Agriculture, Kyushu University

バージョン：

権利関係 : 


\title{
Detection of Tricholoma Matsutake in Soil After FOREST Fire in a Pinus Densiflora Forest in Korea
}

\author{
Joo Young CHA ${ }^{1}$, Kun Woo CHUN ${ }^{2}$, Sang Yong $\mathrm{LEE}^{2}$, \\ Si Young $\mathrm{LEE}^{3}$ * and Shoji OHGA
}

\author{
Laboratory of Forest Resources Management, Division of Forest Ecosphere Management, \\ Department of Forest and Forest Products Science, Kyushu University, \\ Sasaguri, Fukuoka 811-2415, Japan \\ (Received May 18, 2009 and accepted July 13, 2009)
}

\begin{abstract}
We examined T. matsutake survived in soil after forest fires in T. matsutake-produced forest in the pre-fire period and the situation of damages from forest fire in stands. We established a square plot of $(50 \mathrm{~m} \times 50 \mathrm{~m})$ in a burned site and divided it into 100 square quadrats of $(5 \mathrm{~m} \times 5 \mathrm{~m})$. Tree density of $P$. densiflora, the dominant tree species, in plot was $2,104 /$ ha, with a basal area accounting for $99 \%$. The percentage of dead pine trees was $52.1 \%$, which is less than in other species as $88.6 \%$ and $100 \%$ of Quercus spp. and Prunus sargentii, respectively. In PCR amplification using the T. matsutake-specific primer pair, the 400-bp fragment was found in 29 of 100 soil sample s from each quadrat and in control cultures. The relationship to the percentage of crown damage differed significantly $(p=0.0026)$, with means between Tm and nTm of 59\% and 70.5\%, respectively. Moreover, the difference between BLT and nBLT on crown damage was highly significant in the $U$-test $(p=0.0008)$. Therefore, $P$. densiflora in inner quadrats with low crown damage had T. matsutake on their roots. T. matsutake favor $P$. densiflora and mineral soils with low litter rather than under BLT with a thick humus layer. The area of T. matsutake from a forest fire in crown damage to $P$. densiflora will eventually decrease in relation to the increase in BLT. Hence, the species distribution in understory vegetation such as shrub and BLT is an important factor for overstory tree survival from forest fires. In conclusion, the management of T. matsutake forest by controlling tree density and taking out understory vegetation is considered a good method for decreasing damage from forest fires.
\end{abstract}

\section{INTRODUCTION}

Tricholoma matsutake (S. Ito et Imai) Sing. is an ectomycorrhizal basidiomycete that produces economically important edible mushrooms "matsutake" in association with Pinus spp. plants in the Northern Hemisphere (Ogawa, 1975; Hosford et al., 1997). The prices of this mushroom as a seasonal delicacy favored by the Japanese, Chinese and Korean are so expensive. But the annual yield of T. matsutake in Japan has dramatically decreased since the 1940s. The yield of 52 tons in 2002 was only $0.4 \%$ of the 12,000 tons recorded in 1941 (Ministry of Agriculture, Forestry, and Fisheries of Japan). So, almost volumes of consumption in Japan are imported mainly from Korea, China and North America. A similar decline in T. matsutake production has occurred in China (Xu and Ribot, 2004) and Korea (Lee, 2008) probably because of recent global climate change leading to drought and warming as well as due to post-World War II urban development and pine wilt disease (Hosford et al., 1997; Hall et al., 2003).

In recent, forest fires occurred in east cost regions of Korea in Goseong in May 1996, in Donghean in April 2000, and in Yangyang in May 2005 and burned 3762 ha,

\footnotetext{
Field Science Center for Northern Biosphere, Hokkaido University, Nayoro 096-0071, Japan

2 Division of Forest Resource, College of Forest and Environmental Sciences, Kangwon National University, Chuncheon 200-701, Korea

The Professional Graduate School of Disaster Prevention Technology, Kangwon National University, Samcheok 245-711, Korea

* Corresponding author (E-mail: lsy925@kangwon.ac.kr)
}

23794 ha, and 973 ha, respectively, of forested land (Chun, 2005). These fires led to tremendous economic losses of 202.7 (Goseong), 100 (Donghean), and 18.3 (Yangyang) million US dollars. Because Pinus densiflora Sieb. et Zucc. which had been associated with mainly T. matsutake production is the dominant species in those forests and destroyed by these fires. Therefore, the forest fires damaged not only the pine trees but also reduced wood resources and local income. Specific countermeasures for the recovery of $T$. matsutake in forests are needed in these regions.

In fungal molecular methods, polymerase chain reaction (PCR) analysis of the internal transcribe spacer (ITS) region of nuclear rDNA has proven to be a reliable methods for identification at species level (Burn et al., 1991; Bridge et al., 1998). This method is also acceptable to ectomycorrhizal fungi and has been used in both fields and laboratories (Henrion et al., 1992; Gardes and Burns, 1993; Karen et al., 1997). In recent, Kikuchi et al. (2000) developed a specific ITS primers pairs for $T$. matsutake detection in soils. This method is useful for the identification of T. matsutake from the field research (Guerin-Laguette et al., 2005).

Therefore, our objectives in this study were 1) to examine T. matsutake population that survived in soils after fires using PCR analysis of ITS region of nuclear rDNA, and 2) to clarify the situation of individual damages of $P$. densiflora associated with surviving T. matsuteke in T. matsutake produced forest in the pre-fire period. This information will be useful in managing $T$. matsutake-producing forests for the conservation of the fungal resources and reforestation of $T$. matsutake forests after fires. 


\section{MATERIALS AND METHODS}

\section{Study site and field survey}

The study site $\left(38^{\circ} 05^{\prime} \mathrm{N}, 128^{\circ} 35^{\prime} \mathrm{E}\right)$ was in the region of the Yangyang forest fire of May 2005, close to the East Sea in Kangwon Province, Korea, partly on the eastern slope of the Baekdu-Tekgan range (Fig. 1). A field survey was carried out in February 2006, 10 months after the fire. We established a square plot of $(50 \mathrm{~m} \times$ $50 \mathrm{~m}$ ) in a burned site on the southeastern slope and divided it into 100 square quadrats of $(5 \mathrm{~m} \times 5 \mathrm{~m})$. We measured overall tree height and diameter at breast height (dbh, $1.3 \mathrm{~m}$ ) of trees more than $1.3 \mathrm{~m}$ tall. Trees $>1.3 \mathrm{~m}$ were divided into two classes, dying and surviving, and individually scored according to the percentage of fire damage to stems and crowns.

\section{Soil sampling}

On hundred soil samples of 50-100 g were collected from the 10-15-cm layer of soil in each quadrat after the

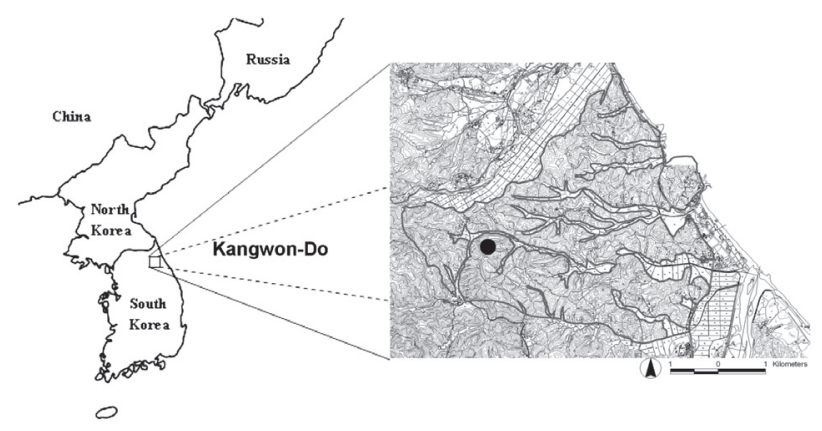

Fig. 1. Location of the study site field survey in February 2006. Samples were kept in a freezer at $-80{ }^{\circ} \mathrm{C}$ until DNA extraction.

\section{DNA extraction and polymerase chain reaction (PCR)}

Fungal DNA was extracted from $0.25-1.00 \mathrm{mg}$ of each soil sample using the UltraCleanTM Soil Isolation Kit (MO BIO), according to the manufacturer's instructions. The internal transcribed spacer (ITS) region, including the 5.8S ribosomal DNA (rDNA) segment, was amplified using primers specific for T. matsutake TmF and TmR (Kikuchi et al., 2000) regions. Each 50- $\mu \mathrm{l}$ amplification reaction mixture contained $5 \mu \mathrm{l} 10 \mathrm{x}$ G-Taq buffer, $4 \mu \mathrm{l} 2.5 \mathrm{M}$ dNTP, $5 \mu \mathrm{l} 5 \mathrm{x}$ Tuning buffer (Cosmo Genetech, Seoul, Korea), and 0.5 $\mu \mathrm{l}$ G-Tag DNA polymerase (Cosmo Genetech, Seoul, Korea). Amplifications were performed using a 2720 Thermal Cycler (Applied Biosystems). Initial denaturation started at $95^{\circ} \mathrm{C}$ for 10 min, followed by 35 cycles of denaturation at $95^{\circ} \mathrm{C}$ for $30 \mathrm{~s}$, annealing at $59{ }^{\circ} \mathrm{C}$ for $30 \mathrm{~s}$, and extension at $72^{\circ} \mathrm{C}$ for $1.5 \mathrm{~min}$; a final extension was performed at $72{ }^{\circ} \mathrm{C}$ for $8.5 \mathrm{~min}$. The presence or absence of a specific fragment band was visualized by $2 \%$ agarose gel electrophoresis and ethidium bromide staining.

\section{RESULTS}

\section{Characteristics of the forest structure of a post- fire stand}

Table 1 shows stand condition after the forest fire. The forest was composed of $P$. densiflora, Quercus mongolica Fisch, Q. aliena Blume, Q. serrata Thunb., Q. variabilis Blume, and Prunus sargentii Rehd. Tree

Table 1. Stand condition of the study site

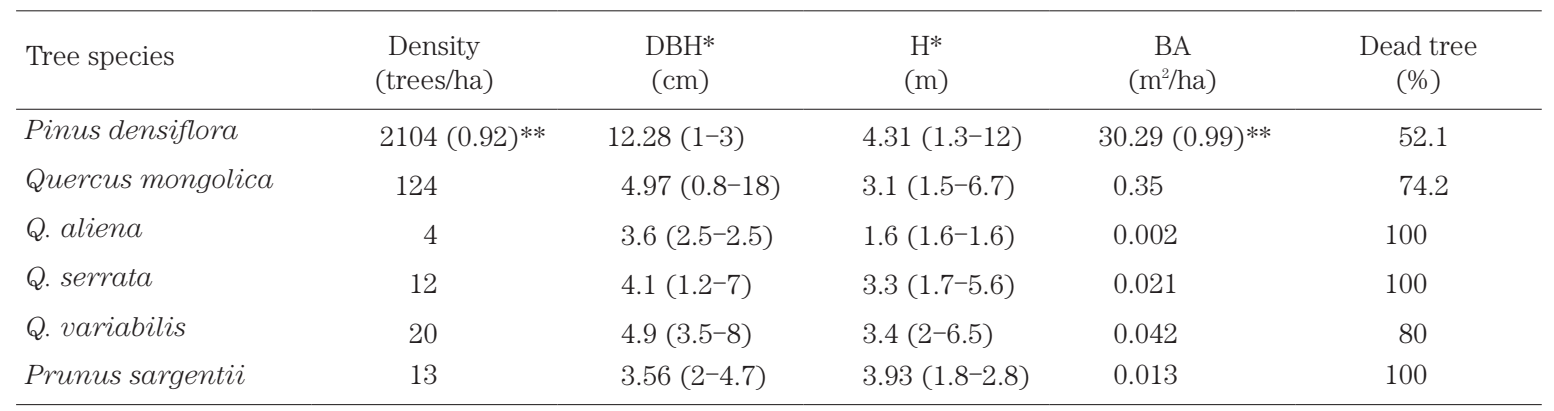

* Values are mean and range ** Ratio of $P$. densiflora.

Table 2. Percentage of dead trees among the ranges of height

\begin{tabular}{|c|c|c|c|c|c|c|}
\hline Height $(\mathrm{m})$ & $\begin{array}{c}\text { P. densiflora } \\
\text { dead no./total no. }\end{array}$ & $(\%)$ & $\begin{array}{c}\text { Quercus spp* } \\
\text { dead no./total no. }\end{array}$ & $(\%)$ & $\begin{array}{c}\text { P. sargentii } \\
\text { dead no./total no. }\end{array}$ & $(\%)$ \\
\hline$<5$ & $235 / 358$ & 66 & $27 / 35$ & 77.1 & $3 / 3$ & 100 \\
\hline $5-10$ & $39 / 169$ & 23.1 & $4 / 5$ & 80 & - & - \\
\hline $10<$ & $0 / 1$ & 0 & - & - & - & - \\
\hline Total & $274 / 526$ & 52.1 & $31 / 40$ & 77.5 & $3 / 3$ & 100 \\
\hline
\end{tabular}

\footnotetext{
* Inculding Quercus species as 31 of mongolica, 1 of aliena, 3 of serrata, and 5 of variabilis.
} 
Table 3. Percentage of dead trees among the ranges of $\mathrm{DBH}$

\begin{tabular}{|c|c|c|c|c|c|c|}
\hline DBH (cm) & $\begin{array}{c}\text { P. densiflora } \\
\text { dead no./tatal no. }\end{array}$ & $(\%)$ & $\begin{array}{c}\text { Quercus spp* } \\
\text { dead no./total no. }\end{array}$ & $(\%)$ & $\begin{array}{c}\text { P. sargentii } \\
\text { dead no./total no. }\end{array}$ & (\%) \\
\hline$<10$ & $160 / 193$ & 82.9 & $30 / 38$ & 78.9 & $3 / 3$ & 100 \\
\hline $10-20$ & 112/292 & 38.4 & $1 / 2$ & 50 & - & - \\
\hline $20<$ & $2 / 41$ & 4.9 & - & - & - & - \\
\hline Total & $274 / 526$ & 52.1 & $31 / 40$ & 77.5 & $3 / 3$ & 100 \\
\hline
\end{tabular}

* Same in Table 2.

Table 4. Relationship between dead trees and the percentage of stem damage in ranges

\begin{tabular}{|c|c|c|c|c|c|c|}
\hline Damage $^{* *(\%)}$ Tree species & $\begin{array}{c}\text { P. densiflora } \\
\text { dead no./tatal no. }\end{array}$ & (\%) & $\begin{array}{c}\text { Quercus spp* } \\
\text { dead no./total no. }\end{array}$ & $(\%)$ & $\begin{array}{c}\text { P. sargentii } \\
\text { dead no./total no. }\end{array}$ & (\%) \\
\hline$<30$ & $89 / 258$ & 34.5 & $0 / 8$ & 0 & - & - \\
\hline $30-60$ & $142 / 219$ & 64.8 & $0 / 1$ & 0 & - & - \\
\hline $60<$ & $43 / 49$ & 87.8 & $31 / 31$ & 100 & $3 / 3$ & 100 \\
\hline Total & $274 / 526$ & 52.1 & $31 / 40$ & 77.5 & $3 / 3$ & 100 \\
\hline
\end{tabular}

* Same in Table 2. ** Stem damage.

Table 5. Relationship between dead trees and the percentage of crown damage in ranges

\begin{tabular}{|c|c|c|c|c|c|c|}
\hline Damage $^{* *(\%)}$ Tree species & $\begin{array}{c}\text { P. densiflora } \\
\text { dead no./tatal no. }\end{array}$ & $(\%)$ & $\begin{array}{c}\text { Quercus spp* } \\
\text { dead no./total no. }\end{array}$ & (\%) & $\begin{array}{c}\text { P. sargentii } \\
\text { dead no./total no. }\end{array}$ & (\%) \\
\hline$<30$ & 0/148 & 0 & $0 / 8$ & 0 & - & - \\
\hline $30-60$ & 0/88 & 0 & $0 / 1$ & 0 & - & - \\
\hline $60<$ & $274 / 290$ & 94.5 & $31 / 31$ & 100 & $3 / 3$ & 100 \\
\hline Total & $274 / 526$ & 52.1 & $31 / 40$ & 77.5 & $3 / 3$ & 100 \\
\hline
\end{tabular}

* Same in Table 2. ** Crown damage.

density of $P$. densiflora, the dominant tree species, was 2,104/ha, with a basal area accounting for 99\%. The mean height of $P$. densiflora was larger than that of the other tree species, and the percentage of dead pine trees was $52.1 \%$, which is less than in other species. The relationship between dying trees and tree height is shown in Table 2. The percentage of dying $P$. densiflora in relation to tree height was $66 \%$ of trees $<5 \mathrm{~m}$ tall and $23.1 \%$ of trees 5-10 $\mathrm{m}$ tall. There was a high percentage of dying trees with a DBH $<10 \mathrm{~cm}$ (Table 3), and a high percentage of trees of $P$. densiflora and Quercus spp. had damaged stems (Table 4). In terms of crown damage, although there were no dead trees in the $<30 \%$ and $30-60 \%$ crowns, almost all trees of over $60 \%$ died (Table 5).

\section{Detection of $T$. matsutake in post-fire soils}

In PCR amplification using the T. matsutake-specific primer pair, the 400-bp fragment was found in 29 of 100 soil samples and in control cultures (Fig. 2). In quadrat nos. $6,10,11,14,16,19,23,29,30,33,38,39$, $42,43,45,49,52,56,57,58,60,61,64,65,67,88,90$, 92, and 93, T. matsutake with gray-colored cell were detected (Fig. 3). The percentage of dead $P$. densiflora in each quadrat to the total pine number was assessed.
All detected quadrats containing T. matsutake, except nos. 16, 43 and 52, had surviving $P$. densiflora, while only one tree survived in quadrats $38,61,88$, and 92 . There was no difference between the percentage of dead trees per quadrat and detection of T. matsutake. More than half of the quadrats (55.5\%) containing T. matsutake were on stony soils.

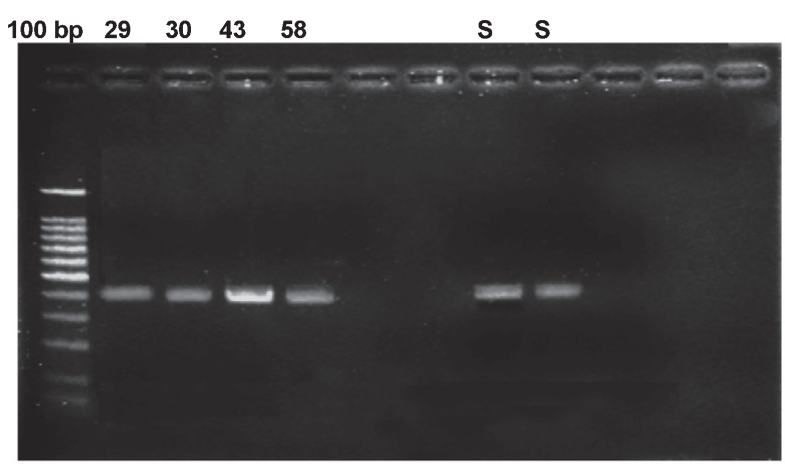

Fig. 2. Amplication with the T. matsutake specific primer pair TmF/TmR (29, 30, 43, 58, quadrat nos,; S, hyphae of $T$. matsutake from pure culture). 


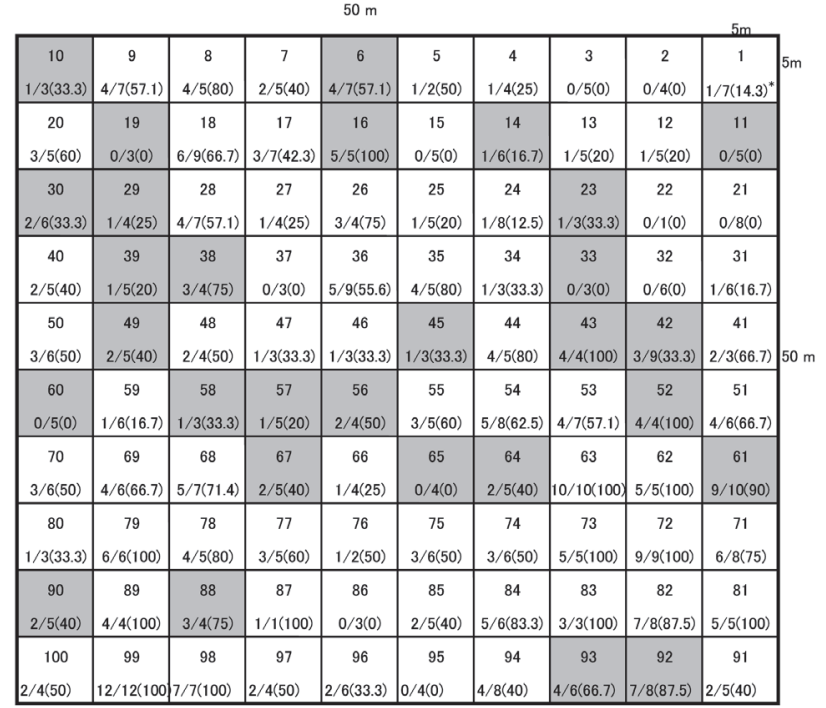

Fig. 3. Quadrats of survival T. matsutake with grayish cells.

* Number of dead tree/total number of tree (\% of dead tree)

\section{DISCUSSION}

Surviving T. matsutake were detected in 29 of 100 quadrats after the forest fire in this former T. matsutake production forest. Pinus densiflora is the dominant tree, occupying $99 \%$ of total basal area, and is the symbiont for T. matsutake, but only 252 trees (47.9\%) survived the fire. Although four of the quadrats in which $T$. matsutake were detected had only one living tree, living T. matsutake hyphae were found in the soil. Thus the presence of the host tree may be the most important factor for T. matsutake remaining in soils after disturbances such as forest fires. However, only three quadrats (nos. 16, 43, and 52) in which T. matsutake were detected contained none living trees. It is interesting that trees with a DBH of $25.5 \mathrm{~cm}$ and $20.83 \mathrm{~cm}$ were found in the quadrat next to that in which $T$. matsutake were detected. The living T. matsutake hyphae appear to be associated with the lateral roots of the nearest big $P$. densiflora tree. Mycorrhizal fungi in soil are usually found at depths of $10-15 \mathrm{~cm}$, and T. matsutake can form ectomycorrhizal associations with the lateral roots of juvenile $P$. densiflora seedlings (Yamada et al., 2006). Guerin-Lagutte et al. (2005) succeeded in establishing T. matsutake mycorrhizae on long root segments of 50-year-old $P$. densiflora trees. Therefore, some large trees from the populations in the forest are very important for the preservation of the biota.

In terms of height and DBH of surviving trees, there was no significant difference in a $U$-test between $\mathrm{Tm}$ (inner tree of quadrats containing T. matsutake) and nTm (inner tree of quadrats without T. matsutake) (Table 6) Therefore, mycorrhizal infection by T. matsutake may not be influenced by the growth of adult $P$. densiflora in nature. Seedlings of $P$. densiflora, on the other hand, show better growth with symbiont T. matsutake than non-infected seedlings (Yoshimura, 2004).
Table 6. Relationship between Tm and nTm, and the height, DBH and the percentage of stem and crown damage caused by the forest fire in average and U-test

\begin{tabular}{lccc}
\hline & \multicolumn{2}{c}{ Average* $^{*}$} & \\
\cline { 2 - 3 } & Tm** & nTm*** & \\
\hline Height (m) & 5.41 & 5.09 & \\
& $(2.2-9.7)$ & $(1.7-12)$ & 0.0839 \\
& 16.21 & 15.1 & \\
DBH (cm) & $(6-30)$ & $(4.5-28)$ & 0.0871 \\
& 30.33 & 34.34 & \\
Stem damage (\%) & $(2-82.61)$ & $(0.33-100)$ & 0.2067 \\
& 59.04 & 70.47 & \\
Crown damage (\%) & $(5-100)$ & $(5-100)$ & 0.0026 \\
& & & \\
\hline
\end{tabular}

* Values are mean and range (Min.-Max.). ** Inner tree of quadrats containing $T$. matsutake. ***Inner tree of quadrats without T. matsutake.

Table 7. Relationship between BLT and nBLT, and the percentage of stem and crown damage caused by the forest fire in U-test

\begin{tabular}{lccc}
\hline & \multicolumn{2}{c}{ Average* $^{*}$} & \\
\cline { 2 - 3 } & \multicolumn{1}{c}{ BLT $^{* *}$} & nBLT*** & \\
\hline Stem damage (\%) & $\begin{array}{c}37.27 \\
(4.26-100)\end{array}$ & $\begin{array}{c}31.87 \\
(0.33-100)\end{array}$ & 0.0568 \\
& 76.18 & 64.41 & \\
Crown damage (\%) & $(5-100)$ & $(5-100)$ & 0.0008 \\
\hline
\end{tabular}

* Values are mean and range (Min.-Max.). ** Inner tree of quadrats with BLT. ***Inner tree of quadrats without BLT.

Although the relationship between Tm and nTm and the percentage of stem damage caused by the forest fire was not significant in the $U$-test, the relationship to the percentage of crown damage differed significantly $(p=0.0026)$, with means between $\mathrm{Tm}$ and $\mathrm{nTm}$ of $59 \%$ and $70.5 \%$, respectively (Table 6 ). Although the relationship between broadleaf trees (BLT; inner trees of quadrats with BLT) and nBLT (inner trees of quadrats without BLT) and the percentage of stem damage caused by the forest fire was not significant in the $U$-test, the difference between BLT and nBLT was highly significant in the $U$-test ( $\mathrm{p}=0.0008$ ) (Table 7). The mean crown damage in BLT was $76.2 \%$, and that in nBLT was $64.4 \%$. Crown damage to BLT in forest fires is an important factor as these provide connecting materials from the ground to the crown fire. This is particularly important in the studied forest where the mean height of BLT was $2.99 \mathrm{~m}$ (range $1.5-6.7 \mathrm{~m}$ ) while the mean height of $P$. densiflora was $4.3 \mathrm{~m}$ (1.3-12.0 m). Moreover, almost all oak trees as BLT in this study area were resprouting from stumps. Pinus densiflora in inner quadrats with low crown damage had T. matsutake on their roots. T. matsutake favor $P$. densiflora and mineral soils with low litter rather than BLT with a thick humus layer. The area of $T$. matsutake from a forest fire in crown damage to $P$. 
densiflora will eventually decrease in relation to the increase in BLT. Hence, the species distribution in understory vegetation such as shrub and BLT is an important factor for overstory tree survival from forest fires.

In conclusion, the management of $T$. matsutake forest by controlling tree density and taking out understory vegetation is considered a good method for decreasing damage from forest fires. Moreover, the T. matsutake production from managed pine forests is higher than that from abandoned forests. Yoshimura (2004) suggested removing BLT, shrubs, herbs, and the humus layer for the improvement of T. matsutake forests. If T. matsutake forests that were productive before a fire contain $P$. densiflora, it is recommended that reforestation with this pine should be undertaken soon after the fire because T. matsutake hyphae were found to survive in soils after the fire. Choung et al. (2004) reported that pre-fire pine forests have been converted to oak-dominated stands immediately after the fire on the east coast. This could lead to the suppression of $P$. densiflora seedlings by taller BLT sprouts (Choung, 2002). Changes in soil pH after a fire should also be considered, and Sawamoto et al. (1997) reported that the soil pH became alkaline in Siberian forests after fire. Alkaline soils containing Douglas-fir, sequoia, and beech seedlings also suffer from increased damping-off caused Rhizina undurata Fr. ex Fr. more than those in acidic soils (Schonhar, 1955). Other soil-borne diseases caused by Rhizoctonia solani Kuhn and Fusarium spp. can result in damping-off of coniferous seedlings on neutral to alkaline soils (Tint, 1945; Ito, 1950; Sato and Shoji, 1964). Pinus densiflora saplings should be grown in nurseries for immediate artificial plantation in recovering $T$. matsutake forests after forest fires.

\section{ACKNOWLEDGEMENTS}

This study was carried out with the support of the 2005 Specialized Priority Program for Disaster Prevention of Kangwon National University, a 'Forest Science \& Technology Projects (No. S210809L010110)' provided by Korea Forest Service in Korea, and a grant-in-aid from Heiwa Nakajima Foundation in Japan. We thanks to Mr. Ho Sung Kim who kindly supported study site in his private T. matsutake forest, to Mr. Sang Kil Ye, Sun Kun Lee and Se Yong Lee for helps on the DNA extraction, and to Yun Jin Kim, Jin Ho Lee and Young Hyup Lim for the field survey.

\section{REFERENCES}

Bridge, P. D., D. K. Arora, C. A. Reddy and R. P. Elander 1998 Application of PCR in mycology. CAB International, Wallingford

Bruns, T. D., T. J. White and J. W. Taylor 1991 Fungal molecular systematics. Ann. Rev. Ecol. Syst., 22: 525-564

Choung, Y. 2002 Forest fires and vegetation responses in Korea.
In Ecology of Korea. Edited by Lee, D., J. C. Choe, Y. Son, S. Yoo, H.-Y. Lee, S.-K. Hong and B.-S. Ihm. Bumwoo Publishing Co. Seoul. pp. 119-137

Choung, Y., B.-C. Lee, J.-H. Cho, K.-S. Lee and I.-S. Jang 2004 Forest responses to the large-scale east coast fires in Korea. Ecological Research, 19: 43-54

Chun, K. W. 2005 Diagnosis and application of the new methods of restoration in forests damaged by the large-scale east coast fires in Korea. The first report. Korea Forest Conservation Movement. pp. 150 (In Korean)

Gardes, M. and T. D. Bruns 1993 ITS primer with enhanced specificity for basidiomycetes-application to the identification of mycorrhizae and rust. Mol. Ecol., 2: 113-118

Guerin-Laguette, A., N. Matsushita, F. Lapeyrie, K. Shindo and K. Suzuki 2005 Successful inoculation of mature pine with Tricholoma matsutake. Mycorrhiza, 15: 301-305

Hall, I. R., Y. Wang and A. Amicucci 2003 Cultivation of edible ectomycorrhizal mushrooms. Trands Biotechnol., 21 433-438

Henrion, B., F. Le Tacon and F. Martin 1992 Rapid identification of genetic variation of ectomycorrhizal fungi by amplication of ribosomal RNA gene. New Phytol., 122: 289-298

Hosford, D., D. Pilz, R. Molina and M. Amaranthus 1997 Ecology and management of the commercially harvested American matsutake. USDA general technical report PNW-GTR-412

Ito, K. 1950 Damping-off of coniferous seedlings on nursery. Forestry Technical Series, 1: 1-24 (In Japanese)

Karen, O., N. Hogberg, A. Dahlberg, L. Jonssson, and J. Nylund 1997 Inter-and intraspecific variation in the ITS region of rDNA of ectomycorrhizal fungi in Fennoscandia as detected by endonuclease analysis. New Phytol., 136: 313-325

Kikuchi, K., N. Matsushida, A. Guerin-Laguette, A. Ohta and K. Suzuki 2000 Detection of Tricholoma matsutake by specific ITS primers. Mycol. Res., 104: 1427-1430

Lee, W. H. 2008 Cultural characteristics and mycelial mat formation using mass production inoculum by Tricholoma matsutake. PhD thesis, Kangwon National University, Chuncheon, Korea, pp. 97 (In Korean)

Ogawa, M. 975 Microbial ecology of mycorrhizal fungus Tricholoma matsutake (Ito et Imai) Sing. in pine forest. II. Mycorrhizal formed by T. matsutake. Bull. Gov. Forest Exp. Station, 278: 21-80

Sato, K. and T. Shoji 1964 Relationships between soil pH and occurrence of damping-off on coniferous seedlings. 75th Nichirinkou. pp. 381-384 (In Japanese)

Sawamoto, T., R. Hatano, T. Yajima, K. Takahashi, A. P. Isaev, T. C. Maxmov and B. I. Ivanov 1997 Soil respiration in Siberian -Tiger ecosystems with different history of forest fire. In Proceedings of the sixth Symposium on the joint Siberian Permaforest studies between Japan and Russia 1997. Edited by Mori, S., Kanazawa, Y. and G. Inoue. Tsukuba, Japan, pp. $112-123$

Schonhar, S. 1955 Erfahrungsberichte aus der Wuttembergischen Forstlichen Versuchsanstalt. 1, Keimlingfaule und Wurzelfaule im Pfanzgarten. Allg. Forstz. 10: 165-166

Tint, H. 1945 Studies in the Fusarium damping-off of conifers. II. Relation of age of host, $\mathrm{pH}$, and some nutritional factors to the pathogenicity of Fusarium. Phytopath., 35: 440-457

$\mathrm{Xu}, \mathrm{J}$. and J. Ribot 2004 Decentralization and accountability in forest management: case from Yunnan, southwest China. Eur. J. Develop. Res., 14(1): 153-173

Yamada, Y., K. Maeda, H. Kobatashi and H. Murata 2006 Ectomycorrhizal symbiosis in vitro between Tricholoma matsutake and Pinus densiflora seedlings that resembles naturally occurring 'shiro'. Mycorrhiza, 16: 111-116

Yoshimura, F. 2004 This is how we've got! Matsutake cultivation. Toronto, pp. 109 (In Japanese) 